\title{
Margaret of Austria's portrait collection: female patronage in the light of dynastic ambitions and artistic quality
}

\section{DAGMAR EICHBERGER}

During her regency in Mechelen, the Archduchess Margaret of Austria (1480-1530), daughter of Emperor Maximilian, assembled a remarkable col. lection of artefacts. Paintings such as the Amolfini Wedding by Jan van Eyck, the set of panels by Juan des Flandes (fig. 1) and Michel Sittow and the Double Portrait by the Master of Frankfurt (fig. 2) can be counted among the highlights of her collection. While it was well known to her contemporaries that Margaret of Austria had one of the finest art collections in the Netherlands, many art historians have overlooked the significant role played by her as collector and patron of the arts. ${ }^{1}$ The unusually rich set of inventories and courtly accounts that still exist make it possible to reconstruct the nature and growth of Margaret's collection from 1493 up to the time of her death in 1530. A preliminary analysis of these sources reveals that Margaret's collection of art objects was particularly strong in two areas, religious art works and secular portraiture. ${ }^{2}$

In all, Margaret owned almost one hundred portraits which she kept in different sections of her personal apartments. As was shown in an earlier essay, a large number of her portraits were arranged and displayed for dynastic purposes in her official portrait gallery and her library. "The present study, which follows on from the earlier analysis of the portrait gallery, investigates the remaining twenty-five portraits which were kept outside Margaret of Austria's portrait gallery (premiere chambre) and library. For this purpose, the study will concentrate on the art objects in the bedroom (seconde chambre a chemynee) and the study of the regent (petit cabinet). Attention will also be given to the question whether the concept of artistic quality was of significance to Margaret as collector or not.

Unfortunately, only a very small number of portraits from the former collection in Mechelen still exist. As is the case with so many of these early

I would like to thank Jaynie Anderson and Anne-Marie Legaré for their helpful comments on this paper.

Th. DaCosta Kaufmann, 'From treasury to museum: the collections of the Austrian Habsburgs', in The Cultures of Collecting, ed. J. Elsner and R. Cardinal (London, 1994), 137-54; E. Scheicher, Die Kunst- und Wunderkammern der Habsburger (Vienna, 1979).

${ }^{2}$ This essay is part of a larger study on the art collection of Margaret of Austria in Mechelen. This project has been funded by the Australian Research Council and the University of Melbourne.

'D. Eichberger and L. Beaven, 'Family members and political allies: the portrait gallery of Margaret of Austria in Mechelen', Art Bull, 77, no. 2 (1995), 225-48. 
collections, Margaret's possessions were dispersed after her death in 1530 . While most of the portraits were inherited by her niece, Mary of Hungary, ${ }^{4}$ and even remained in Mechelen for a couple of years, few of these works can be traced much further than to the third quarter of the sixteenth century. $^{5}$

The time frame covered by this paper is the period between 1507 and 1530, when Margaret of Austria (fig. 3) lived in Mechelen as regent of the Netherlands and acted as foster mother for the children of her brother Philip the Fair. Soon after the archduchess's return from Savoy, she decided to establish herself permanently in this town which formed part of her personal power base. Margaret was to become the centre of a court which fulfilled an important political function within the large empire of Charles V. By fostering literature, music and art she made her mark in the sphere of courtly patronage in northern Europe. Margaret of Austria belongs to a small group of contemporary women who became active collectors and patrons at a certain stage of their lives.

In her youth, Margaret had already spent several years in Mechelen at the court of her close relative Margaret of York, the third wife of her grandfather Charles the Bold. As Margaret of York's old living quarters were deemed too small, additional buildings were acquired for the newly appointed regent of the Netherlands. Extensive renovations of the old structures, as well as the planning and construction of new sections, occurred as soon as Margaret of Austria arrived in Mechelen. The so-called Palais de Savoie, named after the domain of her late husband Philibert of Savoy (fig. 4), was probably not completely finished in Margaret's lifetime but was nevertheless ready to be used as her main residence from where she ruled her court. The inventory of $1523 / 4$ makes detailed references to the living quarters of the regent, which is further evidence of the fact that she lived in the newly built palace at least from that time onwards.

Most of our information about the actual portraits in her collection derives from two key inventories dating from 1516 and $1523 / 4 .{ }^{6}$ While the two inventories overlap to a certain degree, several of the paintings listed in 1516 do not reappear in the later inventory. ${ }^{7}$ The two records frequently provide

4. van den Boogert and J. Kerkhoff, Maria van Hongarije. Koningin tussen keizers en kunstenaars (1505-1508), exh. cat. (Zwolle, 1993).

"For this reason, this investigation will rely heavily on a close analysis of the inventories of 1516 and $1523 / 4$ and use individual works which have survived the ordeals of time to support these findings.

'J. Finot, 'Fragment d'un inventaire de tableaux et d'objets d'art', Inventaire sommaire des archives départementales du Nord, antérieures à 1790 (Lille, 1895), série B, tome vili, 208-12; A. Le Glay (ed.), Correspondence de l'Empereur Maximilien ler et de Marguerite d'Autriche, sa fille, gouvermante des Pays-Bas de 1507 à 1519, publiée d'après les manuscrits originaux (Paris, 1839), t. 11, 468-6.2217 - hereafter Le Glay (1839); H. Michelant, 'Inventaire des vaisselles, joyaux, tapisseries, peintures, manuscrits, etc. de Marguerite d'Autriche, régente et gouvernante des Pays-Bas, dressé en son palais de Malines, le 9 juillet $1523^{\prime}$ (Paris, BN no. 128 des Cinq Cents de Colbert), Académie Royale des Sciences, des Lettres et des Beaux-Arts de Belgique, Bulletins de la Commission royale d'histoire, 3rd ser., 12 (1871), 33-75 and 83-136 - hereafter Michelant (1871).

${ }_{7}$ This is for instance the case with the double portrait by the Master of Frankfurt (fig. 2) which is listed only in the 1516 inventory. 
complementary information on the same object. The fragmentary inventory of 1516 is much more specific in regard to artists' names, and the storage and maintenance of specific objects. It is however less informative as far as the location and display of objects are concerned. This lack of information can be explained in part by the fact that the Palais de Savoie was still under construction. It can be assumed that at this point the collection had not yet been permanently installed. ${ }^{8}$

One of the strong points of the inventory of $1523 / 4$ is the attention paid to the distribution of portraits within the various rooms of the palace. Apart from a small number of portraits which were added later to the original list of artefacts and household items, all objects can be located with a high degree of certainty. In fact, the location of the various items has turned out to be of utmost importance in establishing the purpose and function of each specific room and consequently of the portraits therein.

The sequence of rooms which formed Margaret of Austria's private apartments can best be reconstructed from both civic records and the inventory of $1523 / 4$. Based on these sources one can identify eight rooms, all of which contained her private possessions: a chapel, a library, the premiere chambre followed by the riche cabinet, the seconde chambre a chemynee followed by the adjoining petit cabinet, the cabinet empres le jardin and a room for jewels, gold and silver plate. These are the descriptions used in the original documents to describe the living quarters of the regent. Unfortunately, the terms applied do not always indicate the main function of each of these room. In some instances it is therefore necessary to deduce the purpose of the room from its contents. The seconde chambre a chemynee for example, is the only room which contained a bed, a private altar, a table, and several chests and cupboards. We therefore have to assume that the seconde chambre a chemynee was her bedroom. The adjoining petit cabinet contained a diamond-shaped table, as well as several sets of writing utensils and a few books. This room can be identified as Margaret of Austria's study.

At the time the later inventory was taken, that is in 1523/4, Margaret owned in total eighty portraits, not counting the six devotional diptychs and triptychs which also included family portraits. If one adds these devotional portraits and the portraits which had been commissioned from Jan Vermeyen in $1530,{ }^{9}$ Margaret of Austria's collection of portraits came close to one hundred objects. These portraits were located in three main areas of the palace: the premiere chambre, the library and the bedroom with adjoining study. The largest concentration of portraits was to be found in the premiere chambre and the library. As has been discussed in more detail elsewhere, the premiere chambre served predominantly as her official portrait gallery. The

\footnotetext{
"A more detailed study on the reconstruction of the building history and original arrangement of the living quarters of the regent and her courtiers is currently being undertaken by Markus Hörsch and Dagmar Eichberger.

${ }^{9}$ H. J. Horn, Jan Comelisz Vermeyen: Painter of Charles V and His Conquest of Tunis (Dornspijk, 1989), I, 7-9 and 60 n. 49 .
} 
remaining portraits, a little less than one-third of her collection, were kept in the bedroom and study.

The selection and display of portraits in the premiere chambre leaves no doubt that this room was a consciously designed portrait gallery of considerable size. The close analysis of the thirty portrait panels in the premiere chambre has revealed that there was a clear logic behind the choice of images and their display. Through these portraits the regent of the Netherlands intended to convey very specific messages to her visitors. The systematic representation of Margaret's family, be they members of the Burgundian, the Habsburgian or the Spanish line, clearly demonstrates one rationale behind the display. By showing her Burgundian ancestors and other important relatives, the portrait gallery provided visual support and justification for her position of authority in Mechelen. For this purpose particular attention was given to the Burgundian line and to the Order of the Golden Fleece. As regent of the Netherlands, Margaret represented not just her own interests and ambitions, but first and foremost the concerns of the Emperor. ${ }^{10}$

The second rationale of the premiere chambre was to confirm important political alliances through portraiture, as was for instance the case with King Christian II of Denmark and King Henry VII of England. This concept was furthermore supported by the conspicuous absence of the French royal family in the premiere chambre. That Margaret's motivation behind establishing a portrait gallery was perhaps less one of self-aggrandizement but rather an attempt to glorify the Burgundian-Habsburgian dynasty in a broader sense, is confirmed by the fact that most portraits of the regent herself were kept in other parts of her palace.

Following this analysis of the tightly organized portrait gallery a number of questions arise regarding the other portraits in the palace. If the premiere chambre was laid out as a visual family tree for Margaret and her relatives, which portraits were kept outside this highly public section within the palace? How, for instance, were the portraits in the seconde chambre and petit cabinet arranged?

As mentioned earlier, the seconde chambre a chemynee can be identified as Margaret's bedroom, whereas the petit cabinet served as her study. While it is possible to identify the main purpose of these rooms, it is more difficult to ascertain how private or public these rooms might have been. Comparative research undertaken by Krista de Jonge on the infrastructure of Burgundian residences in Bruges, Brussels and Lille suggests that Burgundian court protocol clearly distinguished between different degrees of privacy within the palace. ${ }^{11}$ It seems as if rooms were traditionally arranged in a kind of

${ }^{10}$ Until 1519 she constantly corresponded with her father, Emperor Maximilian, about the political issues of the day. From 1519 onwards she represented the interests of her nephew Charles V. The prominent position of the Emperor in this portrait gallery is underlined further by the multiple copies of his likeness in the Palais de Savoie. After 1526 Charles $\mathrm{V}$ is the only person represented twice in the premiere chambre.

"K. de Jonge, 'Der herzogliche und kaiserliche Palast zu Brüssel und die Entwicklung des höfischen Zeremoniells im 16. und 17. Jahrhundert', Jahrbuch des Zentralinstituts für Kunstgeschichte, 5/6 (1989/90), 253-82. 
sequential order, leading from the public, to the semi-public, to the most private sections of the palace. Admittance to the most inner parts depended on the degree of closeness to or familiarity with the regent. I am working on the hypothesis that the bedroom and study were Margaret of Austria's most private rooms to which only a small number of privileged individuals gained access.

In 1523/4 Margaret of Austria kept a considerable part of the portrait collection in her bedroom and study. The inventory for this section of the palace lists twenty-five portraits in all, that is eighteen in the bedroom and seven in the study, not counting those in any of the later additions to the inventory. ${ }^{12}$ The walls of both bedroom and study were covered with green taffeta and in the larger room, the seconde chambre a chemmee, sixteen small and large curtains of the same material were put up as covers for some of the paintings. ${ }^{13}$

In contrast to the premiere chambre and the library, portraits were not the dominant feature of the display in the seconde chambre and the petit cabinet. In these two rooms portraits were placed side by side with religious art work, to the extent that devotional objects outnumber the portraits. ${ }^{14}$ Whereas the portraits in the main picture gallery, the premiere chambre, are predominantly single panels without lids or shutters, the material exhibited in the bedroom and study shows much more diversity in medium and size. Portraits occurred in the following media: tapestries, illuminations, carved ivory reliefs, gold metal work, wooden sculpture and of course a large number of panel paintings. In other words, the display must have been far less uniform in nature than the portrait gallery described earlier.

From the evidence provided through the written sources we can gauge that larger paintings were generally displayed on the bedroom walls. Objects in the petit cabinet, on the other hand were consistently of smaller scale. While we can assume that the systematic distribution of objects by size depended to a certain degree on the actual size of the room itself, the strong emphasis on miniature-sized objects in the petit cabinet must have been closely linked to the concept of the study or studiolo as a place for contemplation, enquiry and close examination. That this room was actually used by Margaret of Austria as a private study is strongly suggested by the kind of objects assembled there. Apart from the small-scale art works, Margaret of Austria also kept three small boxes containing writing utensils and several books with bookmarks there. ${ }^{15}$ Other objects worth mentioning are a coffer with coins and medals and several pattern books, as well as playing cards.

\footnotetext{
${ }^{12}$ The later additions can be clearly identified by either the wording, or the script or the location in the manuscript. Additions can be found on fols. $74,74^{*}, 79^{\mathrm{v}}$ and 88 of the original manuscript.

${ }^{13}$ Michelant (1871), 87: 'Item, ladite chambre a chemynee toute tendue de taffetas verd, avec XVI courtines de mesmes taffetas, que grandes que petites, servans a la couvertures desdites painctures et aultres choses estans en ladite chambre ...'

${ }^{14} \mathrm{D}$. Eichberger, 'Devotional objects in book format: diptychs in the collection of Margaret of Austria and her family', in Art, Worship and the Book, ed. B. Muir and M. Manion (forthcoming).

1.5 Michelant (1871), 96/7.
} 
In the case of the petit cabinet the selection of objects seems to have been determined partly by the size of the artefact.and partly by the materials of which they were made. Several of the religious sculptures, for instance, were carved of precious materials such as ivory or amber. With a few exceptions religious as well and non-religious artefacts are described in the inventory as 'petit' or 'bien petit. ${ }^{16}$ Two examples may suffice to illustrate this point. One object is described as 'Item, another small square panel of gilded silver, the background of red enamel. There is a person on the panel, whose face was made from a cameo. On the back of the said cameo there is an inscription which reads "the Duke of Berry". ${ }^{17}$ Another object in the same room was a small triptych made from ivory which had painted portraits of Philip the Good and Charles the Bold on its wings. ${ }^{18}$

Even in those cases when an art work was not explicitly classifed as small, surviving examples indicate that they were moderate in size. Joos van Cleve's portrait of the Emperor Maximilian, which was originally kept in the petit cabinet, is a case in point. This portrait, now in the Kunsthistorisches Museum in Vienna, measures only 27 by 18 centimetres. ${ }^{19}$ As mentioned earlier, Margaret also stored her collection of portrait medals and coins in the petit cabinet. Items such as a pewter medal of King Ferdinand II of Aragon, two gilded silver medals of Margaret of Austria and a silver coin of Philibert and Yolande-Louise of Savoy were kept in specially made boxes and coffers. ${ }^{20}$

The second chambre a chemynee with the adjoining petit cabinet was the most important location within Margaret's private apartments for the display of religious art objects. In all she kept forty-five pieces of religious art in this part of her palace, thirty-three of them in her bedroom and twelve in the study next door. Within this group of religious artefacts we can find devotional diptychs and triptychs which contained likenesses of Margaret of Austria's closest family. Individuals such as Philip the Good, Charles the Bold, Charles V, Juan of Spain and Margaret herself (fig. 5) are either portrayed as pious patrons or are occasionally depicted in the disguise of a saint. ${ }^{21}$

In all there are six diptychs and triptychs showing family members praying in front of the Virgin and Child or a Passion scene. A lost panel painting with the portraits of Margaret of Austria and Emperor Charles $V$ belongs in this group of devotional portraits. It is described as 'Item, another small

${ }^{16}$ All English quotes from the French inventories of 1516 and $1523 / 4$ are my translations.

17 Michelant (1871), 93: 'Item, ung aultre petit tableau carré, d'argent doré, le fond d'esmail rouge, a ung personnaige ayant le visage fait d'ung camehu, derrier lequel tableau est escript "le duc de Berry" :

14 Michelant (1871), 92: 'Item, ung tableau d'ivoire taillé, bien ouvré, de la Passion Nre Sgr et aultres figures, qui se clot a deux feulletz, esqueulx sont painctz Messgrs les ducz Philippe et Charles de Bourgogne:

${ }^{19}$ Michelant (1871), 92: 'Item, ung aultre tableau de la pourtraiture de l'empereur Maximilien. tenant deux fleurs d'ulletz en sa main, habillé de drapt d'or, pourtant la Thoison".

Michelant (1871), 95.

${ }^{21}$ Michelant (1871), 93: 'Item ung aultre petit tableau de N[ot]re Dame d'ung costel et de Jehan l'Evangeliste et de saincte Marguerite, tirez apres le vif du feu prince d'Espaigne, mary de Madame. aussy apres le vif de Mad. Dame'. 
panel with the head of Our Lady and there is a representation of the current emperor and of Madame on her knees, adoring the said image ... ${ }^{22}$ Another interesting example is a precious diptych depicting Charles the Bold in prayer. It was valued at the high price of 100 livres by Margaret's court painter, Bernard van Orley, not long after her death in 1530. The relevant entry reads as follows: 'Item, a rich and very exquisite double panel of Our Lady . . . and Monseigneur Charles of Burgundy, painted on one wing of the said diptych. [He is] on his knees, is dressed in gold brocade, [and has] a black velvet cushion. There is a book of hours lying on the chair in front of him. ${ }^{23}$

Given that this kind of imagery occurs only in the bedroom and study and not in the premiere chambre, it seems as if Margaret of Austria considered devotional portraits to be less suitable for a room reserved for public display of art such as the official portrait gallery. The close analysis of the inventories has brought to light that the seconde chambre a chemynee contained a private altar with liturgical furnishings such as an altar cloth, a baldachin and a cushion. ${ }^{24}$ Margaret also kept several books of hours in this part of her palace. This evidence strongly suggests that the regent frequently performed her devotions in the seclusion of her own bedroom. Margaret also had a private chapel in her palace in Mechelen, but compared to the seconde chambre a chemynee it seems to have been a rather barren place with very few artefacts. In the context of the private altar, the presence of the devotional portrait diptychs and triptychs in the bedroom takes on a new meaning. We can thus assume that Margaret preferred to keep her devotional portraits and her other religious artefacts in a room which she used regularly for her religious exercises.

If the portraits in the premiere chambre and the library served as an extended pictorial family tree and as a who's-who of political alliances, whose portraits were then admitted to the bedroom and study? Can we assume that the regent had a similarly rigorous program for the images in this part of her palace? Or did a different set of criteria apply to the objects which entered the seconde chambre a chemynee and the petit cabinet? The following observations will show that there is more variety in the selection of individuals displayed in this part of the palace.

In 1523 Margaret kept a secular diptych with a portrait of her brother Philip the Fair and herself as children in her bedroom (fig. 6). ${ }^{25}$ This double

${ }^{22}$ Michelant (1871), 83/4: 'Item, ung aultre petit tableau de Nre Dame en chief ou est la represen. tation de l'empereur moderne et de Madame a genoux, adorant ladite ymaige ...'

${ }^{23}$ Michelant (1871), 88: 'Item, ung tres riche et fort exquis tableau de Nre Dame . . Monsgr le duc Charles de Bourgogne painct en l'ung desdits fulletz, estant a genoux, habillé de drapt d'or a ung coussin de velours noir et une heure estant sur son siege devant luy ...'

Michelant (1871), 74.

${ }^{25}$ Michelant (1871), 86: 'Item, ung petit double tableau vieux ou la representation de feu le roy Dom Philippe et de Madame, du temps de leurs mynorité et portraiture, habillé de drapt d'or'; this diptych has been identified with the panels now kept in the portrait gallery at Schloss Ambras, Innsbruck; see also Eichberger and Beaven, 'Family members and political allies'; the portrait diptych of Margaret and Philip the Fair, now in the National Gallery, London, was probably commissioned at the same time. 
portrait, which had been commissioned around 1493 when marriage negotiations took place between the house of Habsburg and the Spanish court, had been initially kept in the library. By 1523 it had been withdrawn from the library and moved to her bedroom. It may well be that this diptych was taken off the walls of the library because it was considered to be out of date and more recent portraits of Philip the Fair were available for the decoration of both the premiere chambre and the library.

Another peculiarity in relation to the portraiture in her bedroom and study is the abundance of likenesses of Margaret herself. While there was not a single portrait of the regent in the premiere chambre and only one portrait, a marble bust by Conrad Meit, in the library, four portraits of the regent were kept in the seconde chambre and petit cabinet in 1523; a further portrait was added after $1523 .^{26}$

Among the five portraits of Margaret of Austria in this area we can find a pair of miniature wooden portraits by her court sculptor Conrad Meit, depicting Margaret and her second husband Philibert of Savoy (fig. 4). ${ }^{27}$ Portrait busts as such were still quite uncommon in northern Europe at that time. Margaret possessed two pairs of busts, one in marble and one in wood, both by Conrad Meit, who specialized in three-dimensional portraiture. Such portrait busts had been popular among Italian patrons and collectors for quite some time and had only recently been introduced to the North by artists such as Torrigiano. As early as 1510, Margaret herself owned a terracotta bust of Mary of England, which Torrigiano repaired for her at that time. ${ }^{28}$

Another likeness of the regent in the bedroom was a single portrait panel in the format of a woven tapestry which is described in the following words: 'Item, another very rich portrait panel of Madame, made as a tapestry, after life'. ${ }^{29}$ Again, we are looking at a fairly new and experimental medium for portraiture. While tapestries as such had been collected for over a century by the Burgundian court, the notion of the autonomous tapestry portrait emerged only in the early sixteenth century. A further portrait of Margaret of Austria was described as a 'very beautiful portrait of Madame, painted by the deceased Maitre Jacques'. ${ }^{30}$ Maitre Jacques is none other than her highly regarded court artist Jacopo de' Barbari, who worked for Margaret up to the time of his death in about 1516. Among the pieces listed in the petit cabinet there was also a small diptych by Michel Sittow which depicted 'a Saint John and a Saint Margaret, drawn as likenesses of the deceased prince of Spain and of Madame'. ${ }^{31}$ In other words, the diptych by Sittow

\footnotetext{
${ }^{25}$ Soon after the inventory was completed, a fifth portrait of the regent was added to the collection.

${ }^{27}$ See Eichberger and Beaven, 'Family members and political allies', 239-41.

2. Record of payment on 26 April 1510, Arch. Nord. Reg. mand. B 203, fol. 66 as quoted in C. Lowenthal, 'Conrad Meit', PhD thesis (New York University, 1976), 144-5.

"Michelant (1871), 85: 'Item, ung aultre riche tableau de portraiture de Madame, fete en tapisserie apres le vif'.

Ibid.

"Michelant (1871), 93.
} 
represented Margaret of Austria and her first husband Juan of Spain in the guise of their patron saints.

The question then arises as to why Margaret of Austria kept most of the portraits of herself in her bedroom and study and not in the more public areas of the palace. Given Margaret's active involvement in shaping the official portrait collection and commissioning and exchanging portraits for political reasons, it cannot be accidental that the marble bust by Meit is the only likeness of the regent in the premiere chambre and in the library, and that all other portraits are clustered together in her bedroom and study. It may have been a question of decorum for Margaret to keep a fairly low profile in the more official rooms, as she probably saw herself as the delegate of the Emperor rather than a ruler in her own right. That she was nevertheless interested in collecting good quality likenesses of herself is reflected in this selection of portraits in the more secluded parts of the palace.

So far, the analysis of the portraits concentrated on relatives of Margaret of Austria most of whom had already been represented in the official portrait gallery. Who else was exhibited on the walls of the bedroom and study? Among the eighteen portraits in the seconde chambre a chemynee two individuals, Erard de la Marck and Charles Oursin, deserve a special mention. Both were important figures at the court of Margaret of Austria, Oursin the inspector of expenses at the palace in Mechelen, de la Marck a highly influential political player at her court and a member of Margaret's privy council. ${ }^{32}$ As de la Marck and Oursin were neither family members nor political allies of the highest order their portraits did not qualify for being integrated into the display in the official portrait gallery or the library.

In the inventory of 1516 two paintings are connected with Charles Oursin, the maître d'hôtel of the palace in Mechelen, both of which contained his portrait. The first of these paintings depicted a 'beautiful slave girl'." The cover of this unusual image was decorated with portraits of Charles Oursin, his father and Margaret's dog named 'Boute'. The second picture, a small portrait of Oursin, had been painted by Michel Sittow, whose work Margaret greatly admired. ${ }^{34}$ It seems likely that Oursin had given this second painting to Margaret before 1516 as it is listed both in the earlier and the later inventory. Erard de la Marck's portrait (fig. 7) in the seconde chambre a chemynee was painted after 1521 and therefore appears only in the $1523 / 4$ inventory. ${ }^{35}$ Margaret seems to have cared particularly about possessing a portrait of de la Marck, as she herself commissioned Jan Vermeyen to produce another diptych of the Cardinal of Liège several years after the earlier portrait entered the collection.

\footnotetext{
32 P. Harsin, Etudes critiques sur l'histoire de la principauté de Lïge 1477-1795. Le règne d'Erard de la Marck 1505-1538 (Liège, 1955), I, 2; H. Lonchay, "Marck, Erard de la', in Biographie nationale (Belgium), $13(1894-5), 497-512$.

se Glay (1839), 481 .

Le Glay (1839), 481; Michelant (1871), 87.

3ichelant (1871), 86; van den Boogart and J. Kerkhoff, Maria van Hongarije, 322-33.
} 
De la Marck and Oursin had established a close working relationship with the regent in the first decades of the sixteenth century; the presence of their portraits in Margaret's private quarters are a testimony to this. Occasionally, courtiers expressed their attachment to the court by presenting the ruler with an art work or a precious object. This could take the form of a fine portrait or another picture of high artistic value. A case in point is Don Diego de Guevara, the maître d'hôtel of Philip the Fair and Juana of Castille, who stayed in the service of the house of Burgundy for more than forty years. He presented Margaret with two very valuable paintings, a Portrait of a Portuguese Lady and the Amolfini Wedding, ${ }^{36}$ both by Jan van Eyck. Guevara himself was an important collector and patron of the arts. It is most likely that he chose these two objects for their artistic value rather than for their subject matter. While the name of the sitter, Giovanni Arnolfini, is documented in both inventories, we have no reason to believe that Margaret of Austria was particularly interested in him as an individual. Arnolfini was a member of a powerful merchant family from Lucca and had died several decades earlier. His portrait was only one of several portraits of Italian merchants in her collection. ${ }^{37}$

Margaret's regard for the artistic value of the Amolfini Wedding by van Eyck is expressed in the way in which the picture is described. First, the panel is characterized in the inventory as 'ung tableau fort exquis', ${ }^{38}$ Secondly, Margaret of Austria made sure that the painting was adequately protected while it was in her possession. She gave orders to provide the wings, which were then attached to the painting, with a new lock so that it could be closed properly. ${ }^{39}$

In contrast to the portraits in Margaret's official portrait gallery, the identity of a large number of sitters in the seconde chambre a chemynee was not known to the compilers of the inventory. Nine of the twenty-five portraits displayed in this part of the palace are therefore described in very vague terms. In her bedroom, for instance, Margaret kept the portrait of 'a man dressed in black $^{40}$ or the picture of a 'young lady dressed in the Portuguese fashion ${ }^{41}$ or 'the portrait of an old man with a round bonnet'. ${ }^{42}$ Because the persons depicted were unidentified, their appearance is described more extensively.

Michelant (1871), 85-6.

${ }^{37}$ We know of two further paintings of merchants, one of which is described as 'Item, ung aultre tableau d'ung personnaige comme marchant, a rond bonnet, ayant les mains l'une sur l'aultre, la robbe de pourpre, le font dudit tableau verd', Michelant (1871), 84; 'Item, ung aultre tableau d'ung marchant Ytalien a rond bonnet, son habit de couleur de pourpre, le fondz verd, a grosse chevelure', Michelant (1871), 85.

*: Michelant (1871), 86: 'Item, ung aultre tableau fort exquis, qui se clot a deux fulletz, ou il y a painctz ung homme et une femme estantz desboutz touchantz la main l'ung de l'aultre, fait de la main de Johannes, les armes et devise de feu Don Dieghe esdits deux feulletz, nommé le personnaige Arnoult Fin'.

so Finot, 'Fragment d'un inventaire', 209: 'en marge: il a necessite d'y mettre une serrure pour le fermer; ce que Madame a ordonne faire'.

4) Michelant (1871), 84.

4 Ibid. 85-6.

${ }^{42}$ Tbid. 86. 
References are made to the age, sex and dress of the sitter. One can also find comments on specific attributes or the colour of the background. ${ }^{48}$

This preliminary analysis of the portraits in the bedroom and study has shown that the material kept in these two rooms is of a different nature to the material kept in the premiere chambre. Compared to the official portrait gallery, there is far less consistency in relation to the format, shape and materials used. As far as the size of these portraits is concerned one can find objects which are of very small dimensions and objects which are described as relatively large. In respect to the varying shapes of objects, we again encounter diversity rather than uniformity. Single panels are placed next to diptychs and triptychs. Sculptures are displayed next to pieces of jewellery and miniatures. This arrangement is obviously not a continuation of the pattern established in the official portrait gallery but rather an alternative concept of display.

As far as Margaret's relations are concerned it is possible to make some suggestions as to why she might have kept certain images in her bedroom and study. Some of the images in the seconde chambre a chemynee are duplicates or very close copies of works already represented in the premiere chambre. This applies for instance to Joos van Cleve's portrait of the Emperor Maximilian, and also to Mostaert's portrait of Philibert of Savoy and Meit's busts of Margaret and Philibert.

As has been discussed earlier, some of the children's portraits were taken off public view because they were out of date in 1523. In the meantime new portraits had replaced the old ones in the premiere chambre. While there were obviously a number of reasons why certain family portraits were kept in this part of the palace, the choice of objects and the arrangement of the individual works do not point to a specific programme or to a clear structure as was the case in the official portrait gallery. This impression is further sustained by the large number of unidentifiable individuals with no obvious personal link to Margaret of Austria. I have already mentioned the portraits of Italian merchants and the images of Spanish and Portuguese people in this section of the palace. If it was not for the sake of the individual itself that these images were displayed in Margaret's bedroom and study, were there perhaps other selection criteria at work? Or do we have to assume that the arrangement was completely arbitrary, that the display was nothing more than an assemblement of bits and pieces, the residue from the decoration of the other rooms?

A closer look at the way in which objects in the seconde chambre and the petit cabinet are characterized reveals that the descriptions of these objects contain many references and comments on the beauty and quality of the artefacts on display. This applies not just to the portraits but also to some of the religious and mythological works in these two rooms. Comments such

\footnotetext{
43 Unfortunately most of these portaits cannot be identified as the description is too general to make an attribution justifiable.
} 
as 'riche et fort exquis double tableau' or 'bien ouvré' or 'bien fete' occur regularly in this section of the inventory. In comparison with the images in the premiere chambre references to the quality of a work are made more frequently in this section than in the rest of the inventory. Jan van Eyck's double portrait, the Arnolfini Wedding, for example, was characterized as 'ung aultre tableau fort exquis'. The lost portrait of Margaret of Austria painted by Jacopo de' Barbari was also awarded the term 'fort exquise'. In the case of Van Eyck's Madonna by the Fountain (fig. 8), the inventory makes a further reference to the age of the painting - it is described as 'fort anticque'. ${ }^{44}$ In this section of the inventory more attention was given to the artistic value of a work, which includes observations on craftsmenship, age and authorship. The very differentiated terminology used by the cataloguers of the collection reflects their awareness of artistic quality and value. In this context it is also of significance that many of the works in the collection can be attributed to well-known artists. In her bedroom and study, Margaret of Austria had assembled works by a considerable number of highly acclaimed artists such as Michel Sittow, Joos van Cleve, Jacopo de' Barbari, Hieronymus Bosch, Conrad Meit, Jan van Eyck, Hans Memling and Jan Vermeyen.

The image of Acteon by Jacopo de Barbari was described as 'ung aultre tableau exquis'. ${ }^{45}$ The portrait bust by Conrad Meit was described as 'aussi bien fete'. Joos van Cleve's The Infant Jesus and Saint John (fig. 10) was equally cherished for its artistic quality. ${ }^{46}$ It was given the attribute 'fort bien fait'. ${ }^{47}$ While most of the evaluatory comments are positive in character, there are a few examples of negative judgements. In one of the entries from the petit cabinet a painting is described as being of little value. ${ }^{48}$ In 1516 a small wooden panel with the portrait of a king was described as being 'rather badly done ${ }^{\prime}{ }^{49}$ Such positive and negative characterizations of individual art works can be found in the section describing the bedroom and study but occur less frequently in the remaining rooms of Margaret of Austria's private apartments. Jan Gossaert's painting of the dwarfs of the King of Denmark, for example, was the only picture singled out in the library as a painting which was 'very well made. ${ }^{50}$ A second painting by the same artist depicted

Michelant (1871), 87; in the inventory of 1516 the Eyck painting is described as 'faite de bonne main', Le Glay (1839), 481.

${ }_{43}$ Michelant (1871), 86: 'Item ung aultre tableau exquis ou il y a ung homme avec une teste de cerf et ung crannequin au milieu et le bandaige'; see also Le Glay (1839), 479: 'Ung autre grant tableaul d'une teste de cerf et ung arbalstrier avec une arbalestre carnequin. Fait de la main de feu maistre Jacques de Barberis'.

${ }^{46}$ See Jochen Sander, 'Leonardo in Antwerpen: Joos van Cleves Christus und Johannesknabe, einander umarmend', Städel Jahrbuch, n.s. 15 (1995), forthcoming.

${ }^{47}$ Michelant (1871), 86.

Michelant (1871), 93: 'Item, ung autre bien petit tableau de bois, ou il y a une teste d'ung homme eslevee, avec une certaine scripture des deux lignes, fete sus couleur rouge et est bien de petit valeur'.

${ }^{4}$ Le Glay (1839), 482: 'Autre paincture sur thoille a la semblance du roy, lui estant josne prince, assez mal faicte'.

${ }^{50}$ Michelant (1871), 58: 'Item, delivré audit Garde-joyaux depuis cest inventaire fait, la pourtraiture des nayn et nayne du roy de Dannemarcque, faicte par Jehanin de Maubeuge, fort bien fait'. 
the Metamorphosis of Hermaphrodite and Salamacis (fig. 9) and was based on the account of the classical author Ovid. It received the attribute 'a beautiful panel' and was kept in the cabinet empres le jardin. ${ }^{51}$

The range of terms used in assessing the quality of works of art in her collection is quite remarkable and points to a rather finely tuned sense of value, reflecting the owner's taste and discrimination. Not only are the relevant objects ranked according to a differentiated scale of laudatory expressions, but less highly regarded pieces are also clearly described as such. The use of terms such as 'very old' suggest that attention was also given to the age of an object. As these inventories were written strictly for internal use, that is for maintenance purposes and for the documentation of the property of the regent, we can eliminate the possibility of somebody preparing an overly complimentary document. The introductory paragraphs to the inventory of 1516 convey that Margaret of Austria was present when the inventory was drawn up. While the text preceding the second inventory does not state this explicitly, Margaret signed the document and defined the responsibilities of Richard Contault and Etienne Lullier, the keepers of the collection, in great detail. An investigation of the way in which the collection grew and the inventory was kept up to date leaves no doubt that Margaret worked very closely with these two men on the shaping and maintenance of the collection. The fact that several works were given to her by important art collectors such as Don Diego de Guevara and Philip of Burgundy seems to suggest that Margaret was seen as a person who could appreciate the value of paintings by such famous artists as Jan van Eyck and Jan Gossaert. Her patronage of specific artists and her persistence in carrying through artistic projects such as the construction of the church of St Nicholas in Brou gives further weight to the idea that she fully recognized the potential of art and that her taste was highly developed. We know, for instance, that she rejected one of Dürer's gifts of a portrait because she did not like it. ${ }^{52}$ One of the entries in the seconde chambre a chemynee gives testimony to the fact that Margaret of Austria herself painted during periods of leisure. The item is described as follows: 'Item, a fake book, covered in purple velvet. It has two gilded silver clasps with the coat of arms of Madame, inside there are three little bowls, a small silver box, five brushes with silver decoration; this all serves Madame when she paints in her spare time. ${ }^{53}$ We know that this fake book had been made for Margaret of Austria by Jacopo de Barbari.

In conclusion, we can say that the twenty-five portraits in the seconde chambre a chemynee and the petit cabinet cannot be seen as a continuation of the dynastic programme presented in the premiere chambre and the library. There

\footnotetext{
${ }^{31}$ Michelant (1871), 110: 'Item, ung beau tableau auquel est painct ung homme et une femme nuz, estant les pieds en leaue; le premier bort de mabre, le second doré et en bas ung escripteau, donné par Monsgr d'Utrecht'.

${ }^{32}$ H. Rupprich, Dhïrers schriftlicher Nachlass (Berlin 1956), I, 173.

${ }^{5.5}$ Michelant (1871), 77-8.
} 
was no specific message attached to the portraits on display. On the other hand, alternative patterns of interpretation emerge from the analysis of the objects in the bedroom and study, which give us some ideas as to why these artefacts were kept in these two rooms and not in another part of the palace.

In the case of Margaret of Austria's collection; valuable artefacts constituted a significant feature of the decoration of both bedroom and study. The precious paintings, sculptures and decorative arts objects in these two rooms either fulfilled a religious function or were kept here for their artistic value. Devotional diptychs and triptychs with portraits of Margaret and her close family were displayed in this part of the palace because the bedroom was occasionally used as a place of worship. ${ }^{54}$ The privacy of the bedroom and study provided a suitable environment for the various portraits of the regent herself which had been assembled in this part of the palace.

The small-scale objects in the petit cabinet were kept in this secluded chamber because of their size and their material value. While by the early sixteenth century the study had become a common feature at distinguished courts in the Netherlands, France, England and Italy, ${ }^{55}$ little is known to date about the decoration and the actual use of these rooms. In this context the analysis of the petit cabinet in Mechelen and its furnishings has provided some new insights into the private life of the ruling aristocracy.

Secular portraits of Italian merchants and of further anonymous sitters were probably displayed on the walls of her private apartments for the enjoyment of the regent. It can be assumed that some of the religious and the mythological pieces were also cherished foremostly for their artistic value. The use of curtains in both rooms suggests that the display on the walls was intended to be flexible and could be modified according to the occasion. The specific terms in which the individual objects were described clearly demonstrate that Margaret of Austria had a keen eye for quality and that she admired the skill and craftsmanship of individual artists such as Conrad Meit, Michel Sittow and Jan van Eyck. The inventories of the collection in Mechelen therefore not only contain valuable information on the artefacts themselves, but can also point to an early example of art appreciation and connoisseurship in the Burgundian Netherlands. While in this case, artefacts were still kept in the living quarters of the owner, the esteem for art and the care taken in exhibiting the objects prepared the way for the formation of an independent

Sh See also Eichberger (forthcoming), fn. 14 .

s* See de Jonge, Der Palast zu Brüssel; W Liebenwein, Studiolo. Die Entstehung eines Raumtyps und seine Entwicklung bis um 1600 (Berlin, 1977); W. Prinz, Die Entstehung der Galerie in Frankreich und Italien (Berlin, 1970); S. Thurley, The Royal Palaces of Tudor England (New Haven, Conn. and London, 1993), 135-43; S. Ferino-Pagden, 'La Prina Donna del Mondo' - Isabella D'Este. Fï̈rstin und Mäzenatin der Renaissance, exh. cat, Kunsthistorisches Museum Wien (Vienna, 1994); E. Scheicher, 'De vorstelijke Kunst- und Wunderkammer', in E. Bergvelt, D. J. Meijers and M. Rijinders, Verzamelen Van Rariteitenkabinet tot Kunstmuseum (Heerlen, 1993), 15-36. 
keeping place, the Kunst- und Wunderkammer, in the second half of the sixteenth century. ${ }^{56}$

\section{University of Saarbrücken}

O. Impey and A. MacGregor (eds.), The Origins of Muserms: The Cabinet of Curiosities in Sixteenthand Seventeenth-Century Europe (Oxford, 1985); A. Grote (ed.), Marrocosm in Microcosm. Die Welt in der Stube. Zur Geschichte des Sammelns 1450 bis 1800, Berliner Schriften zur Museumskunde, 10 (Opladen, 1994); H. Bredekamp, Antikensehnsucht und Maschinenglaube. Die Geschichte der Kumstkanmer und die Zuhunft der Kunstgeschichte (Berlin, 1993); Das Praunsche Kabinett - Ktunst des Sammelns. Meisteruterke von Dürer bis Caracci, exh. cat, Germanisches Nationalmuseum (Nuremberg, 1994); I, Herklotz, Neue Literatur zur Sammlungsgeschichte', Kunstchronik, 47, no. 3 (1994), 117-35; J. von Schlosser, Die Kunst. und Wunderkanmern dor Spätrenaissance. Ein Beitrag zutu Geschichte des Sammelwesens (Braunschweig, 1978; reprint of the 1908 edition). 


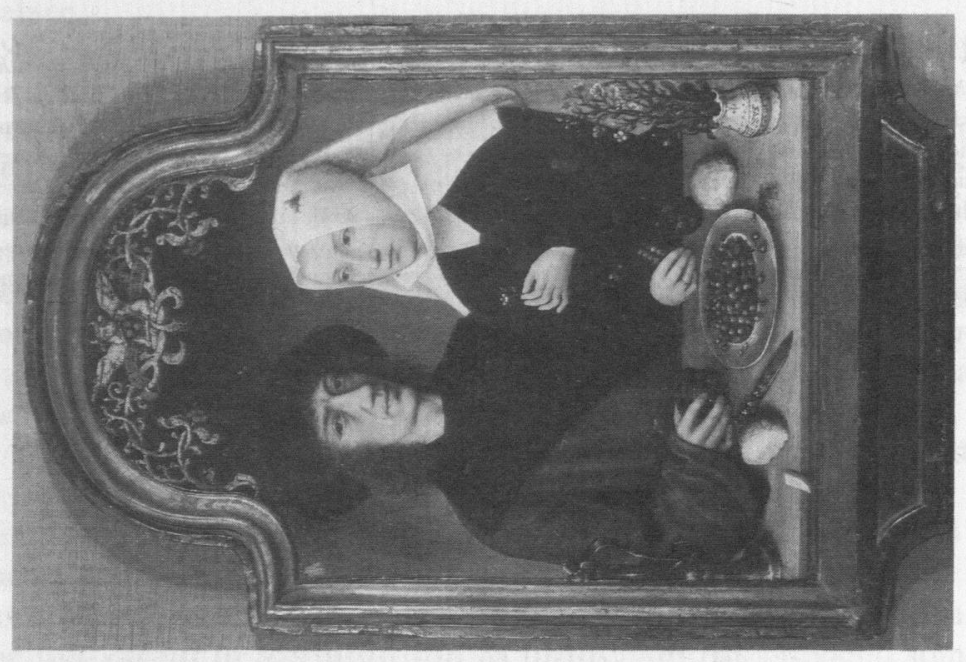

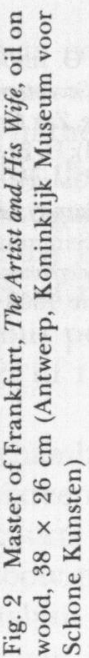

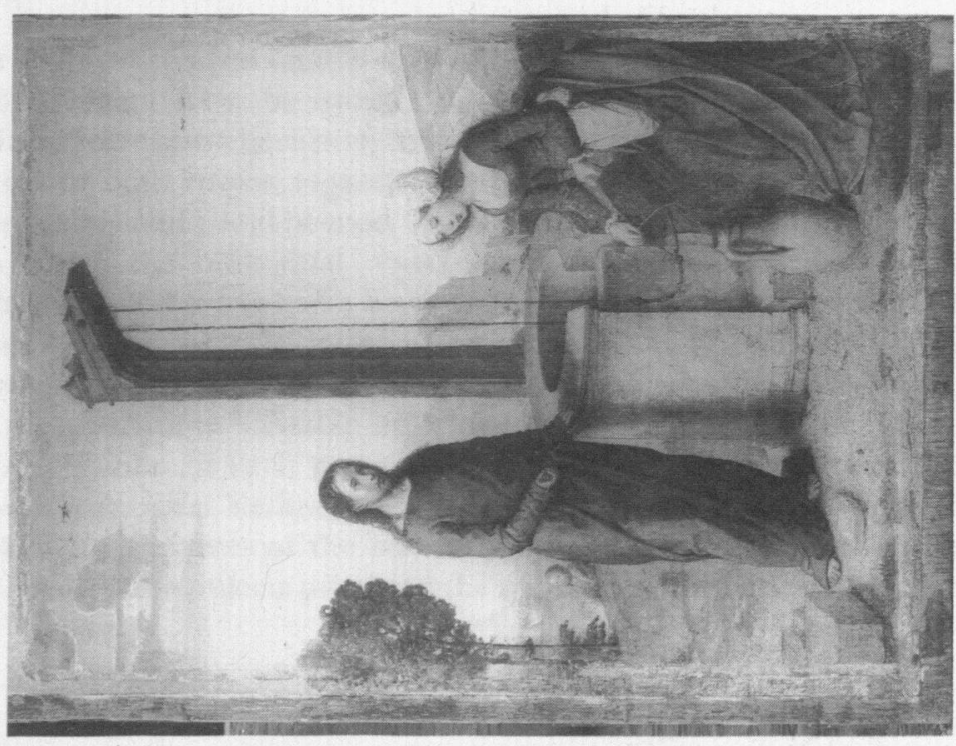

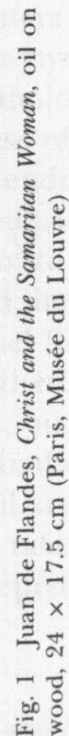



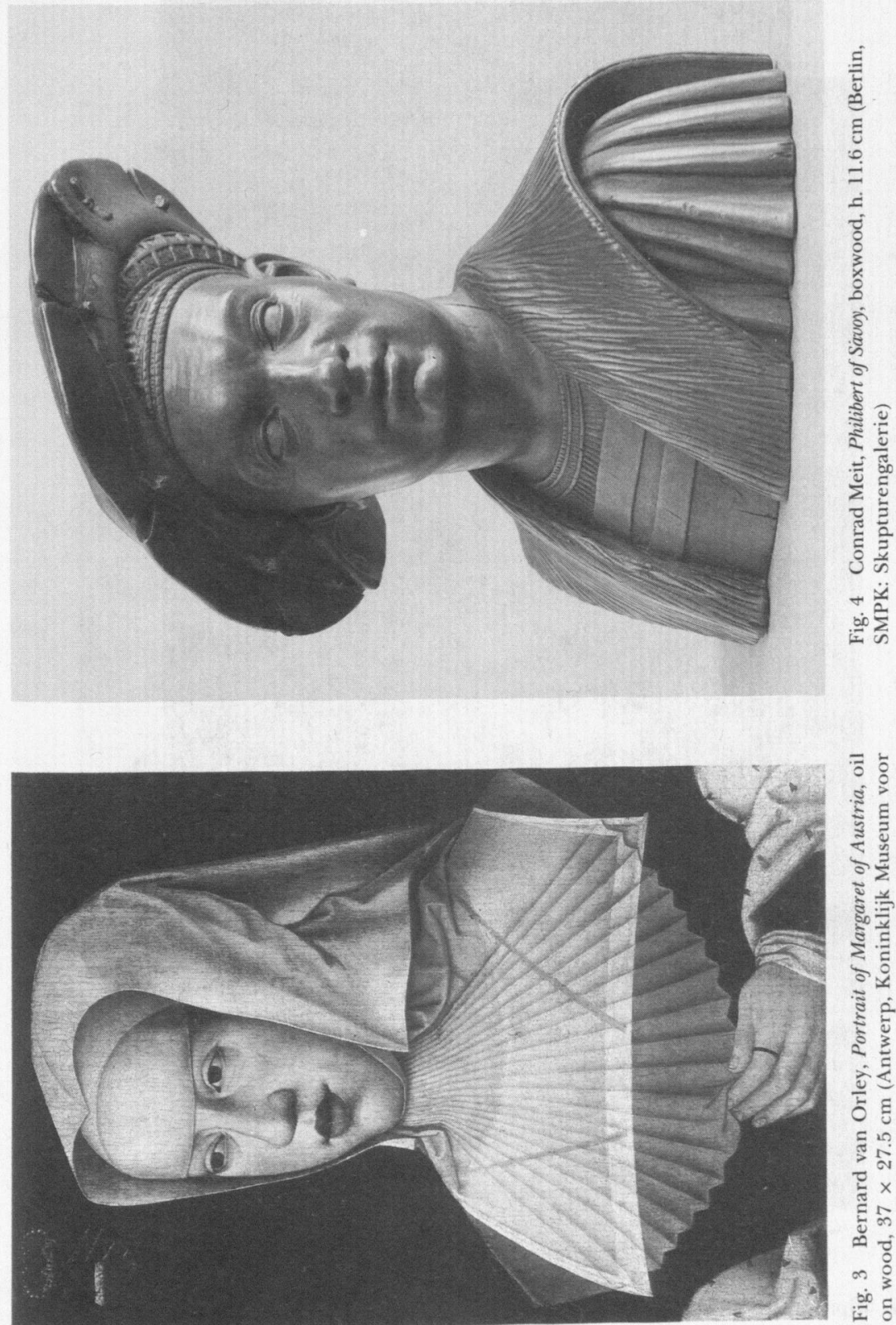

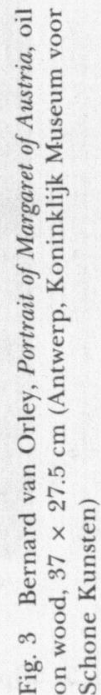




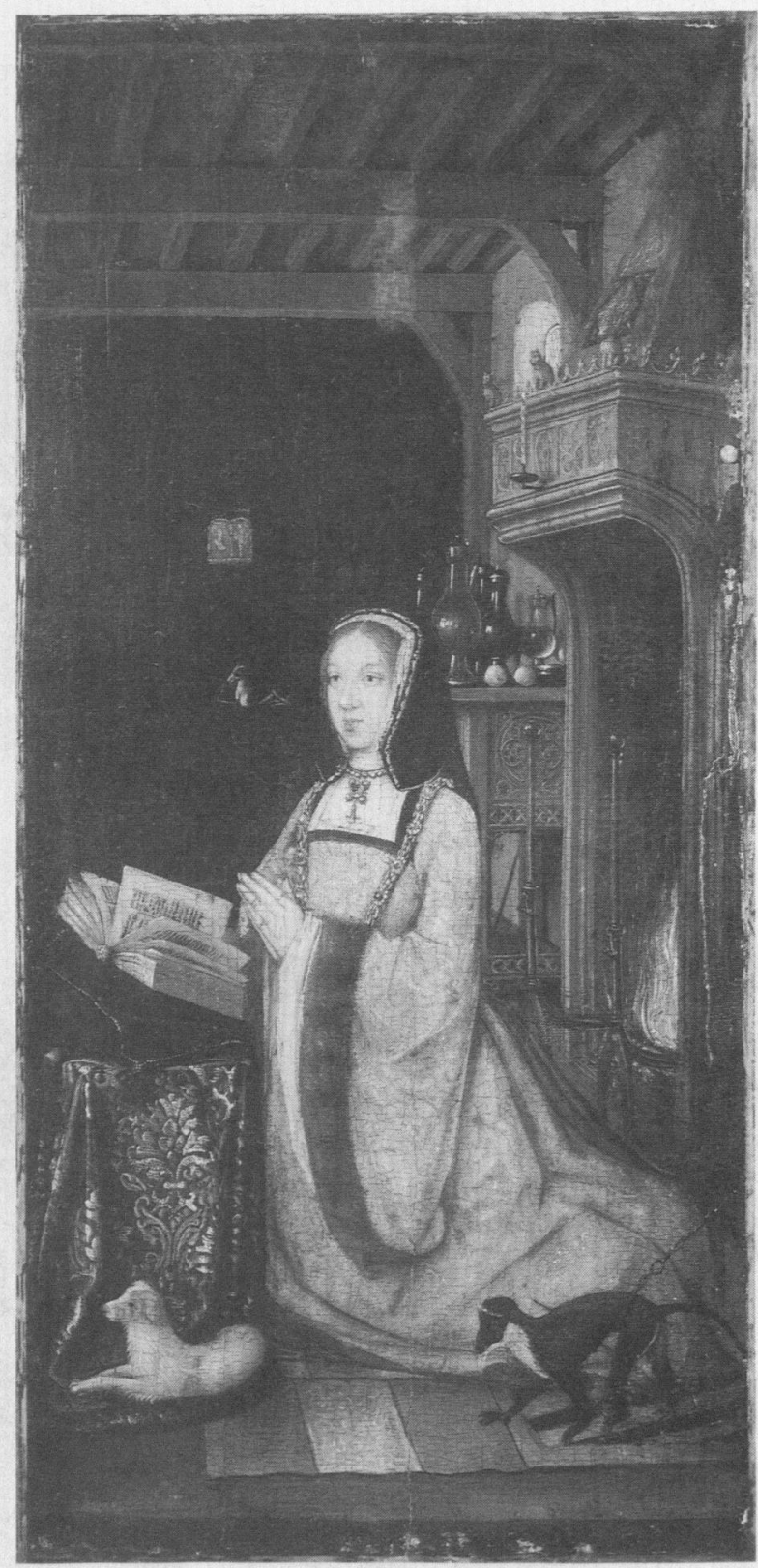

Fig. 5 Diptych attributed to Master of 1499, right half: Margaret of Austria in Adoration of the Virgin Mary, oil on wood, $34.9 \times 23.6 \mathrm{~cm}$ (Ghent, Stedelijk Museum) 


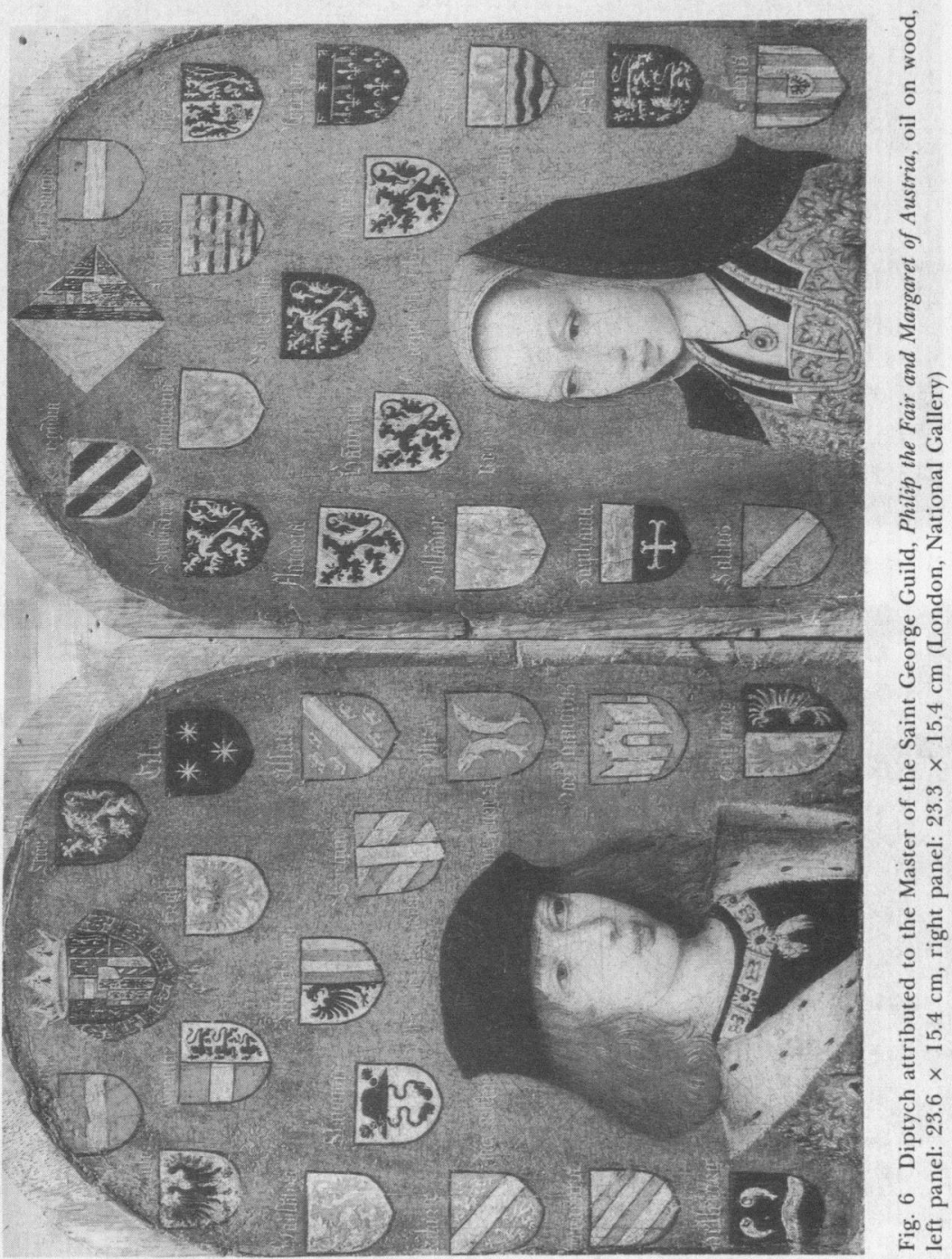



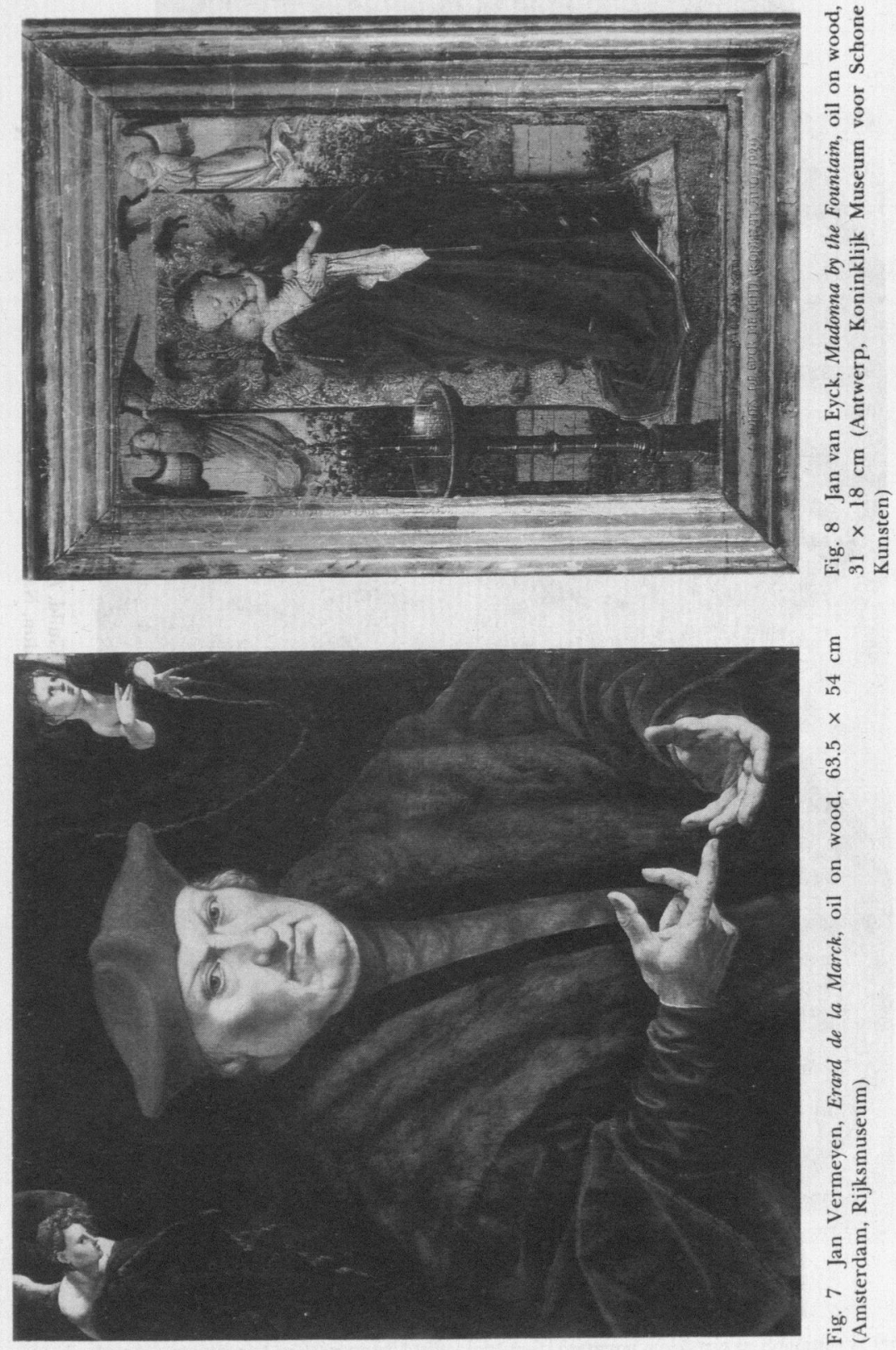

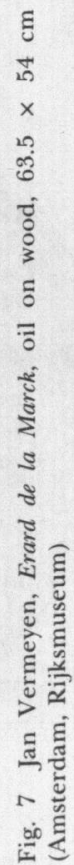




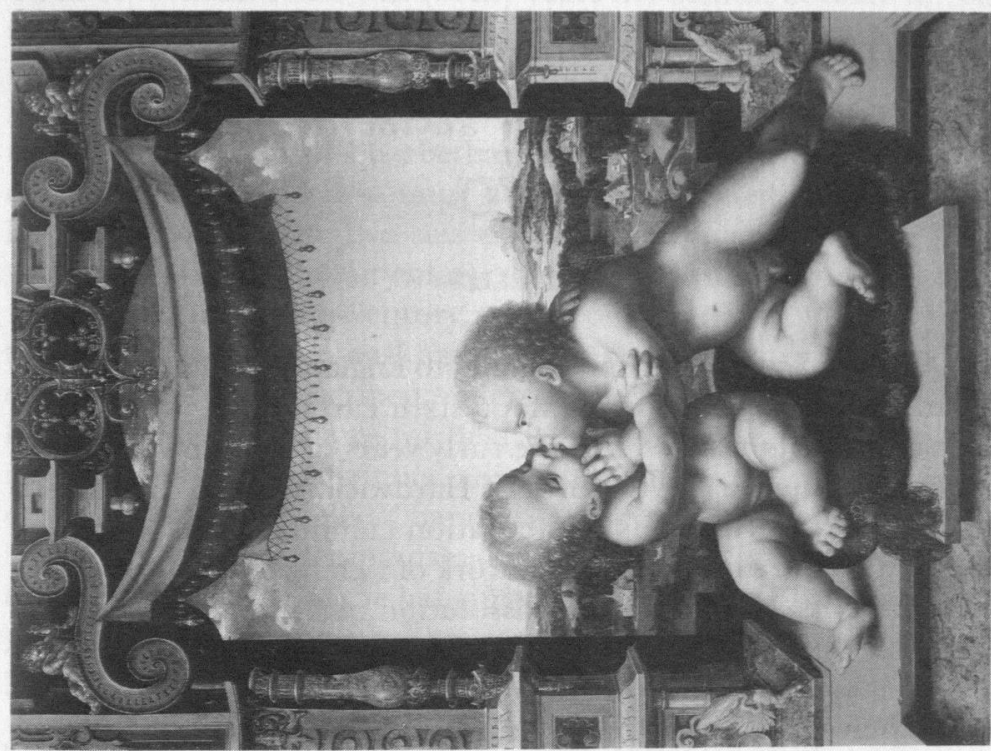

รั

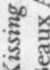

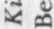

हี ปี

हี

है है

콜

ปู

है हु

है $x$

in 12

N

ป ర్

กี

응

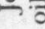

$ㅇ$

ต

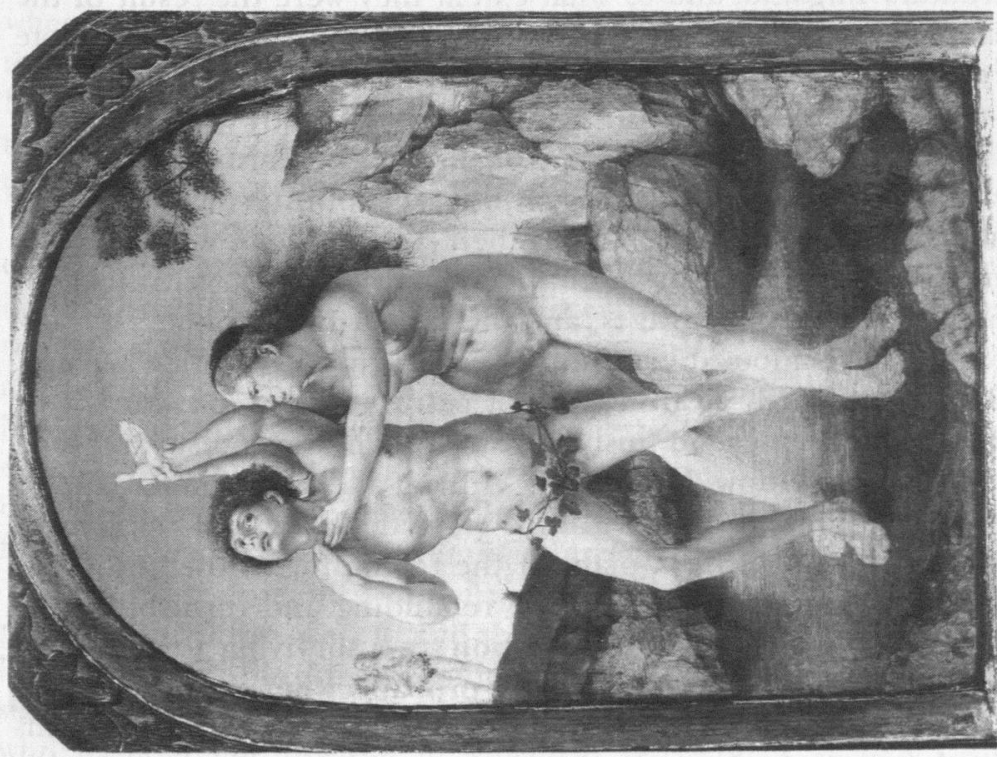

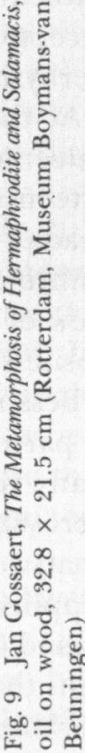

